\title{
Cytogenetic and morphological diversity in populations of Astyanax fasciatus (Teleostei, Characidae) from Brazilian northeastern river basins
}

\author{
Aline Souza Medrado, Alba Vivian Amaral Figueiredo, Ana Maria Waldschmidt, \\ Paulo Roberto Antunes de Mello Affonso and Paulo Luiz Souza Carneiro \\ Departamento de Ciências Biológicas, Universidade Estadual do Sudoeste da Bahia, Jequié, BA, Brazil.
}

\begin{abstract}
In the present work, morphometric and cytogenetic analyses were carried out in populations of the fish Astyanax fasciatus (Characidae) from Contas and Recôncavo Sul River basins (State of Bahia, Brazil), providing new data on the genetic structure of this species along the region. Based on morphologic measurements, we observed that populations from the same hydrographic basin were more similar to each other (Contas and Preto do Costa Rivers), and remarkably divergent from Recôncavo Sul (Mineiro Stream), as indicated by clustering analysis. Cytogenetic data revealed a same diploid number for all populations $(2 n=48)$, but distinct karyotype formulae $(8 M+24 S M+12 S T+4 A$, $\mathrm{FN}=92$ in Contas River, $8 \mathrm{M}+24 \mathrm{SM}+10 \mathrm{ST}+6 \mathrm{~A}, \mathrm{FN}=90$ in Preto do Costa River, and 8M+18SM+16ST+6A, FN = 90 in Mineiro Stream). Ag-NORs were identified at telomeres on a subtelocentric chromosome pair, although multiple ribosomal sites have been detected in some specimens from Contas River. These results show that $A$. fasciatus populations from northeastern river basins are well differentiated and present peculiar cytogenetic features when compared to populations from other regions. Therefore, the apparent chromosomal plasticity of this species, likely to represent a complex of cryptic forms, is corroborated. Finally, we demonstrated that morphological features can be successfully used to support other sources of genetic information.
\end{abstract}

Key words: canonic variables, karyotype, morphometry, NOR.

Received: August 21, 2006; Accepted: May 4, 2007.

\section{Introduction}

The small characin fish Astyanax fasciatus (Characidae, Insertae sedis) was formerly described by Cuvier (1819) as a typical species from "Brazilian rivers". Ever since, systematic studies have highlighted that Astyanax representatives compose distinct species complexes of controversial taxonomy (Reis et al., 2003). So far, the genus comprises 92 valid species and recent descriptions are about to increase this number (e.g. Bertaco and Lucena, 2006; Melo and Buckup, 2006).

Cytogenetic studies in South American freshwater fishes have been extremely useful to reveal inter- and intra-specific genetic differences, bringing out relevant data on cryptic species and the biodiversity evolution in the neotropical region (Almeida-Toledo et al., 2000).

The chromosomal data available on distinct Brazilian populations of Astyanax fasciatus have shown a remarkable diversification of cytotypes and the occurrence of specific variants. The predominant diploid numbers of this

Send correspondence to Paulo Luiz Souza Carneiro. Departamento de Ciências Biológicas, Universidade Estadual do Sudoeste da Bahia, Rua José Moreira Sobrinho s/n, 45200-000 Jequié, BA, Brazil. E-mail: plscarneiro@gmail.com. species are $2 n=46$ and $2 n=48$, but they can range from 45 to 48 and present quite differentiated chromosome formulae (Morelli et al., 1983; Centofante et al., 2003; Pazza et al., 2006, among others). These results, supported by morphological studies (Melo and Buckup, 2006), suggest that the species currently referred as Astyanax fasciatus should be divided into other nominal evolutionary units.

It must be pointed out that most genetic reports on neotropical fish in Brazil are restricted to the main river basins from southern and southeastern regions, whereas minor and isolated river basins are still underrepresented. Thus, essential knowledge on patterns of genetic diversity of several species and populations and their relationship to the evolutionary history or environmental peculiarities of each basin remain unknown.

The northeast of Brazil comprises a small-scale hydrographic system when compared to other Brazilian regions. This condition is mainly related to a dominant semiarid climate over regional rivers, with the exception of some coastal basins located south Bahia and at Maranhão Gulf on the northwestern boundary. Although some rivers, such as Contas and Paraguassu (State of Bahia) are permanent, due to both soil features and location of headwaters at 
Diamantina Plateau, they present intermittent tributaries (Rosa et al., 2003).

In order to increase the information on the genetic diversity of $A$. fasciatus along the northeastern region of Brazil, morphometric and cytogenetic analyses were performed in three populations from distinct hydrographic basins in the State of Bahia. These are the first data on genetic structure of this species in the region.

\section{Material and Methods}

\section{Sampling sites}

Specimens of $A$. fasciatus were collected by using set gill and drift nets at three collection sites: the main channel of Contas River, Preto do Costa River, and Mineiro Stream (Figure 1). The former is the main river of Contas hydrographic basin and represents one of the most important water systems in the State of Bahia. Its headwaters are located at Diamantina Plateau (about 1,500 $\mathrm{m}$ above sea level) and the river flows over $620 \mathrm{~km}$ before reaching the Atlantic Ocean. Samples from Contas River were obtained at its middle part, in the city of Jequié $\left(13^{\circ} 51^{\prime} 51^{\prime \prime} \mathrm{S} / 40^{\circ} 04^{\prime}\right.$ $54^{\circ} \mathrm{W}, 216 \mathrm{~m}$ high). Preto do Costa River $\left(13^{\circ} 45^{\prime} 84^{\prime \prime} \mathrm{S} /\right.$ $39^{\circ} 56^{\prime} 47^{\prime \prime} \mathrm{W}, 423 \mathrm{~m}$ above sea level) is located at the transitional Middle Contas sub-basin, and it is a left margin tributary of Contas River, close to the first collection site (28 km apart). Mineiro Stream (13 $63^{\circ} 54^{\prime \prime} \mathrm{S} / 39^{\circ} 41^{\prime}$ 54 " W, 285 m above sea level) belongs to Recôncavo Sul basin, and its sampling site was situated in the city of Itamari, Mineiro county, located $63 \mathrm{~km}$ from Jequié.

The fish samples were transported to the laboratory and kept in separated tanks prior morphometric and cytogenetic analyses. Each specimen was identified and deposited in the fish collection from Universidade Estadual do Sudoeste da Bahia (BA, Brazil).

\section{Morphometric studies}

Measurements were taken from 30 individuals per population, comprising 15 morphometric characters. Nine of them were based on Lagler et al. (1977): standard length (SL), head length (HL), body height (BH), caudal peduncle height $(\mathrm{CPH})$, interorbital width (IOW), ocular diameter (OD), preanal length (PL), predorsal length (PdL), and head height $(\mathrm{HH})$. The other characters were the distances between dorsal and pectoral fins (DPD), pectoral and pelvic fins (PPD), pelvic and anal fins (PAD), dorsal and anal fins (DAnD), anal and adipose fins (AAD), and dorsal and adipose fins (DAdD), taking the base of the first fin ray as a reference (or the anterior insertion, in the case of adipose fins).

The evaluation of inter-population genetic diversity was accomplished through canonic variables. Grouping analyses were performed using the generalized Mahalanobis $\mathrm{D}^{2}$ distance as a dissimilarity measurement and, subsequently, the Tocher optimization method was applied

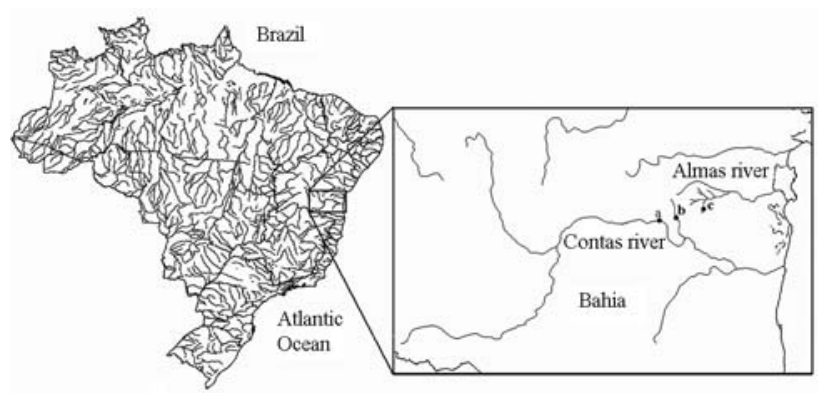

Figure 1 - Hydrographic map of Brazil showing in detail the main rivers for the Contas and Recôncavo Sul basins (State of Bahia) and collection sites of this study: (a) Contas River, (b) Preto do Costa River, and (c) Mineiro Stream.

(Sneath and Sokal, 1973). Statistical analyses were performed with SAS (1997). In addition, data matrices were used in a size-free canonical discriminant analysis - CDA (Reis et al., 1990). This analysis consists of removing the effects of within-group size variation by regression.

The following statistical model was used:

$$
\mathrm{y}_{i t r}=\mu_{t}+P_{i t}+e_{i t r}
$$

where $t=1,2, \ldots 15 ; i=1,2$, and $3 ; r=1,2, \ldots 30 . \mathrm{y}_{i t r}=$ value observed in character $t$, at repetition $r$, in population $i$; $\mu_{t}=$ mean $t$ character value; $P_{i t}=$ effect of the population i on character $t ; e_{i t r}=$ effect of random error associated with the observation $y_{i t r}$.

\section{Cytogenetic studies}

Thirty-five individuals (one male and 34 females) of A. fasciatus from Contas River, 37 animals (six males and 31 females) from Preto do Costa River, and 25 individuals (10 males and 15 females) from Mineiro Stream were cytogenetically analyzed.

Mitotic stimulation was performed on the collected specimens $72 \mathrm{~h}$ prior the cytogenetic preparation, as described by Molina (2001). Metaphase chromosomes were obtained from kidney cells according to Bertollo et al. (1978). The slides were stained with Giemsa at 5\% for conventional analyses. Nucleolar organizer regions were detected by silver nitrate staining (Ag-NOR) (Howell and Black, 1980). The best metaphases were photographed in Imagelink Kodak ISO 25 for chromosome measurements, karyotyping, and NOR analysis. The chromosomal pairs were arranged in decreasing size order and classified as metacentric (M), submetacentric (SM), subtelocentric (ST), and acrocentric (A) (Levan et al., 1964).

\section{Results}

\section{Morphometric analyses}

The results of canonic variables, eigenvalues, and percent variance for each analyzed character are shown in Table 1. The first two canonic variables were able to ex- 
plain $100 \%$ of the total variation existing in the original data, distributed into $61.9 \%$ for the first variable and $38.1 \%$ for the second one.

The less representative features in the genetic diversity of the studied populations were $\mathrm{BH}, \mathrm{AAD}, \mathrm{PdL}$, and IOW, which displayed the highest coefficients in the canonic variable of lowest importance (CV2, Table 2). Less important characters are either invariant or redundant, i.e., they are represented by other highly correlated characters (individually or grouped) (Cruz and Carneiro, 2003).

Clustering analysis among populations was based on the dissimilarity values shown in Table 3 . These numbers represent the estimated Mahalanobis $\mathrm{D}^{2}$ distances between each pair of populations. Through Tocher optimization method, populations were clustered into two groups: one composed of populations from the Contas River basin (Pre-

Table 1 - Canonical variables $\left(\mathrm{CV}_{\mathrm{i}}\right)$, eigenvalues $\left(\lambda_{\mathrm{i}}\right)$, and percent variance $\left(\% \sigma^{2}\right)$ obtained from analysis of 15 morphometric measurements in three Astyanax fasciatus populations from Contas River (Contas and Preto do Costa Rivers) and Recôncavo Sul basins (Mineiro Stream), State of Bahia, Brazil.

\begin{tabular}{lccc}
\hline $\mathrm{CV}_{\mathrm{i}}$ & $\lambda_{\mathrm{i}}$ & $\% \sigma^{2}$ & accumulated $\% \sigma^{2}$ \\
\hline $\mathrm{CV} 1$ & 2.2273 & 61.9 & 61.9 \\
$\mathrm{CV} 2$ & 1.3661 & 38.1 & 100.00 \\
\hline
\end{tabular}

Table 2 - Analysis of canonic variables (CV) based on morphometric data of Astyanax fasciatus populations from two collection sites in the Contas River basin (Contas and Preto do Costa Rivers) and one site in the Recôncavo Sul basin (Mineiro Stream), State of Bahia, Brazil. For description of measurements see Material and Methods.

\begin{tabular}{lcc}
\hline Measurement & CV1 & CV2 \\
\hline SL & -0.573 & 0.700 \\
HL & 1.588 & 0.225 \\
BH & 1.081 & $-1.833^{*}$ \\
CPH & 0.078 & -0.142 \\
IOW & 0.445 & $0.941^{*}$ \\
OD & -0.130 & 0.072 \\
PL & -1.080 & -0.453 \\
HH & -0.217 & 0.341 \\
PdL & 0.286 & $1.058^{*}$ \\
DPD & -0.185 & 0.174 \\
PPD & -0.411 & 0.290 \\
PAD & 0.277 & -0.064 \\
DAnD & -0.137 & 0.304 \\
AAD & -0.661 & $-1.328^{*}$ \\
DAdD & -0.633 & -0.090 \\
Accumulated variation & 0.619 & 0.381 \\
\hline
\end{tabular}

*Less important characteristics on the inter-population differentiation. to do Costa and Contas Rivers) and the other comprising the population from the Recôncavo Sul basin (Mineiro Stream) (Figure 2).

\section{Cytogenetic analyses}

The three $A$. fasciatus populations presented a modal diploid number of 48 chromosomes for both males and females. However, structural differences were observed when comparing the karyotypes from each locality. Specimens from Contas River presented a karyotype formula composed of $8 \mathrm{M}+24 \mathrm{SM}+12 \mathrm{ST}+4 \mathrm{~A}(\mathrm{FN}=92)$, while individuals from Preto do Costa River and Mineiro Stream presented, respectively, $8 \mathrm{M}+24 \mathrm{SM}+10 \mathrm{ST}+6 \mathrm{~A}(\mathrm{FN}=90)$ and $8 \mathrm{M}+18 \mathrm{SM}+16 \mathrm{ST}+6 \mathrm{~A}(\mathrm{FN}=90)($ Figure 3$)$.

Active NOR sites were located at the terminal region of the long arms of a large pair of ST chromosomes in all samples (Figure 3, inbox). Additionally, some individuals from Contas River also showed Ag-NOR marks on the short arms of a small pair of SM chromosomes and, sporadically, of a M chromosome (Figure 3a).

Table 3 - Mean interpopulation distances (Mahalanobis distance estimates based on morphometric data) of Astyanax fasciatus in two sites of the Contas River basin (Contas and Preto do Costa Rivers) and one site of the Recôncavo Sul basin (Mineiro Stream), State of Bahia, Brazil.

\begin{tabular}{lccc}
\hline Site & $\begin{array}{c}\text { Preto do Costa } \\
\text { River }\end{array}$ & $\begin{array}{c}\text { Contas } \\
\text { River }\end{array}$ & $\begin{array}{c}\text { Mineiro } \\
\text { Stream }\end{array}$ \\
\hline Preto do Costa River & 0 & & \\
Contas River & 7.95 & 0 & \\
Mineiro Stream & 11.29 & 12.00 & 0 \\
\hline
\end{tabular}

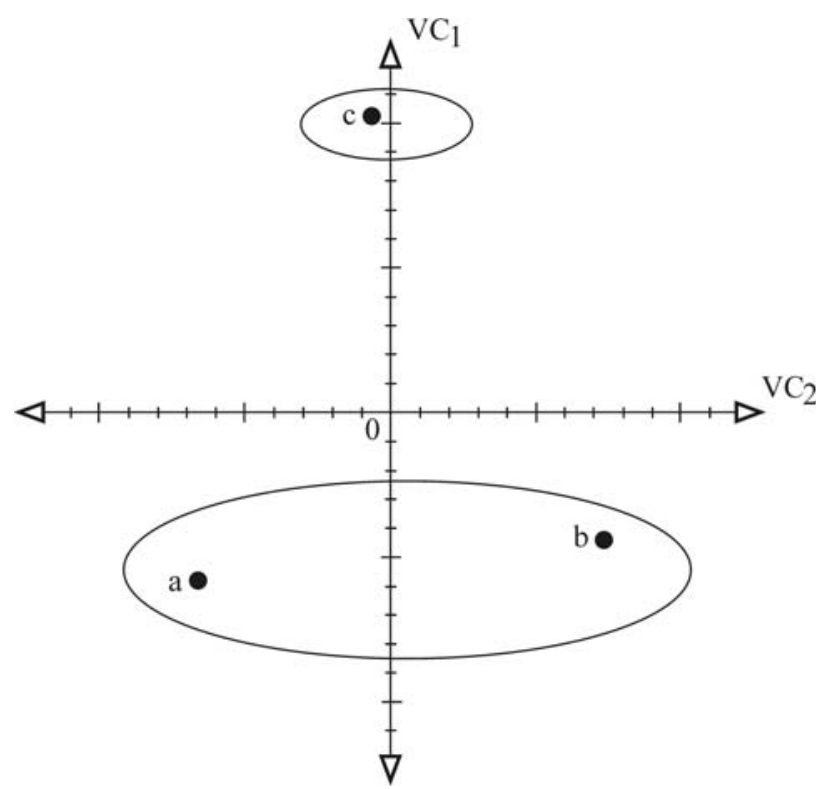

Figure 2 - Graphic dispersal and clustering by Tocher optimization method of three Astyanax fasciatus populations in relation to the first two canonic variables: (a) Contas River, (b) Preto do Costa River, and (c) Mineiro Stream. 
(a)
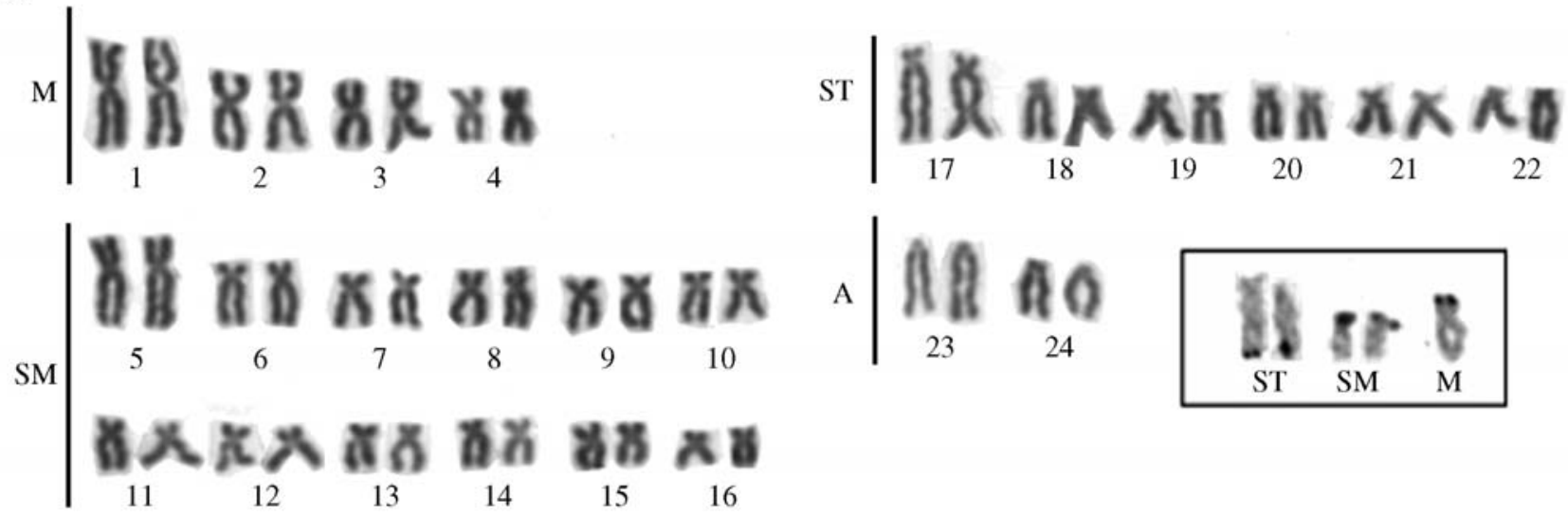

(b)
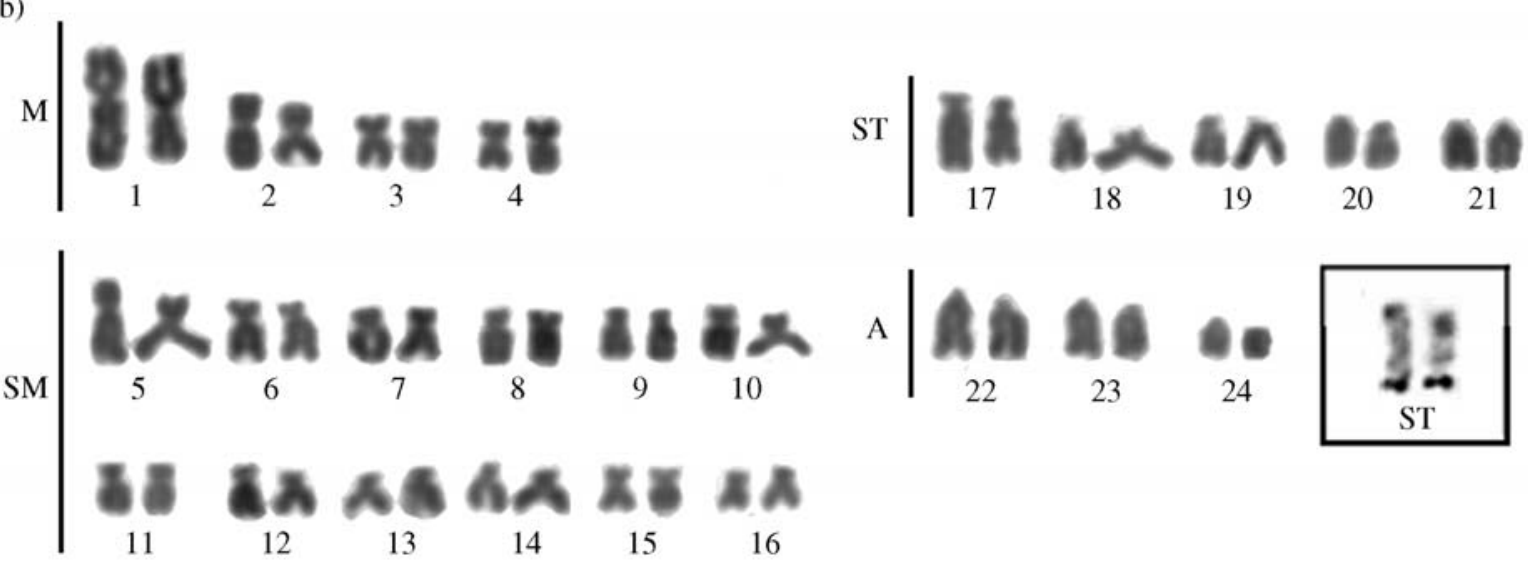

(c)
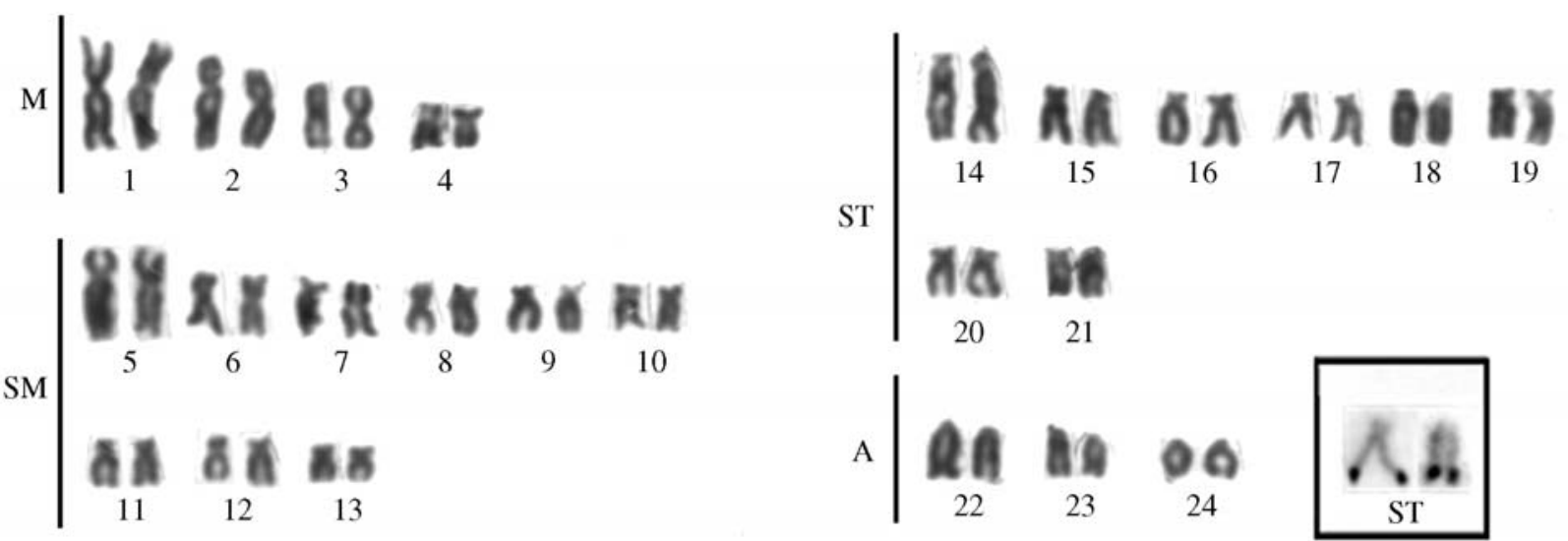

Figure 3 - Giemsa-stained karyotypes and NOR-bearing chromosomes after silver nitrate staining (inbox) of Astyanax fasciatus from Contas River (a), Preto do Costa River (b), and Mineiro Stream (c).

\section{Discussion}

\section{Morphometric data}

The complex patterns of morphometric variation in animals require the use of multivariate statistical analyses (Cavalcanti and Lopes, 1993). In fish, this approach is facilitated since the characters usually present a well-defined hydrodynamic conformation, turning them into a suitable material for morphometric studies (Cavalcanti and Lopes, 1991).

According to Cruz and Carneiro (2003), such studies must include a number of variables to explain, at least, $80 \%$ of the observed variation. In the present work, the first two canonic variables were sufficient to evaluate the morphometric differentiation among populations, since, together, they explained $100 \%$ of the original variation. 
Clustering analyses are often used to divide an original set of observations into distinct groups, based on their similarities or dissimilarities (Cruz and Regazzi, 2001). Analyzing the dissimilarity values and grouping results, we observed that A. fasciatus populations from the Contas River basin (Contas and Preto do Costa Rivers) display a clear morphometric differentiation from the population of the Recôncavo Sul basin (Mineiro Stream). Populations within the Contas River basin were more similar, reflecting their lower degree of isolation. In contrast, the separation between hydrographic basins was evident, placing the population from Recôncavo Sul apart from the others (Figure 2).

\section{Cytogenetic data}

Cytogenetic studies in populations of $A$. fasciatus have revealed a remarkable numerical and structural karyotype variability, as well as the coexistence of different cytotypes in a single river basin (Centofante et al., 2003; Pazza et al., 2006, among others). The data from the present work increase the wide karyotype diversity of $A$. fasciatus, since the cytotypes herein described differ from those previously reported for other hydrographic river basins (Table 4). These results reinforce the apparent chromosomal plasticity of this species, as suggested by Pazza et al. (2006).

Moreover, the karyotype pattern observed in the present work permitted to identify a structural interpopulation variability in A. fasciatus. Despite the maintenance of the diploid number $(2 \mathrm{n}=48)$, specific chromosome formulae were established for each locality. The differences found among populations (and basins) might have been caused by gene flow constraints related to the presence of natural obstacles and/or historical events. In the case of the population from Mineiro Stream, the present results can be correlated to its location in a distinct hydrographic basin, following a typical isolation model.

Although belonging to the same river basin, the genetic separation of the individuals from Contas and Preto do Costa Rivers could be influenced by environmental factors, since the latter presents several small waterfalls, likely able to restrain the dispersal of individuals from one site to another. Reports of karyotype diversity among local neotropical fish populations associated with environmental peculiarities are quite common, particularly within Astyanax species (Moreira-Filho and Bertollo, 1991; Almeida-Toledo et al., 2000). Nevertheless, a higher genetic similarity is expected when comparing populations from the same hydrographic basin. Indeed, a comparison of karyotype macrostructure among the three studied populations presupposes a higher number of chromosomal rearrangements in the differentiation of A. fasciatus from Mineiro Stream (Recôncavo Sul basin) than between populations from the Contas River basin.

Analysis of nucleolar organizer regions has also indicated chromosomal differences between A. fasciatus from
Table 4 - Cytogenetic data on populations of Astyanax fasciatus from Brazil.

\begin{tabular}{lllc}
\hline Collection site, state & $2 \mathrm{n}$ & Karyotypic formula & Reference* \\
\hline Contas River, BA & 48 & $8 \mathrm{M}+24 \mathrm{SM}+12 \mathrm{ST}+4 \mathrm{~A}$ & 1 \\
Preto do Costa River, BA & 48 & $8 \mathrm{M}+24 \mathrm{SM}+10 \mathrm{ST}+6 \mathrm{~A}$ & 1 \\
Mineiro Stream, BA & 48 & $8 \mathrm{M}+18 \mathrm{SM}+16 \mathrm{ST}+6 \mathrm{~A}$ & 1 \\
Mogi-Guaçu River, SP & 48 & $8 \mathrm{M}+22 \mathrm{SM}+12 \mathrm{ST}+6 \mathrm{~A}$ & 2 \\
Mogi-Guaçu River, SP & 48 & $12 \mathrm{M}+20 \mathrm{SM}+8 \mathrm{ST}+8 \mathrm{~A}$ & 3 \\
Mogi-Guaçu River, SP & 47 & $12 \mathrm{M}+19 \mathrm{SM}+10 \mathrm{ST}+6 \mathrm{~A}$ & 2 \\
Mogi-Guaçu River, SP & 47 & $12 \mathrm{M}+20 \mathrm{SM}+10 \mathrm{ST}+5 \mathrm{~A}$ & 2 \\
Mogi-Guaçu River, SP & 47 & $12 \mathrm{M}+21 \mathrm{SM}+10 \mathrm{ST}+4 \mathrm{~A}$ & 2 \\
Mogi-Guaçu River, SP & 47 & $13 \mathrm{M}+20 \mathrm{SM}+8 \mathrm{ST}+6 \mathrm{~A}$ & 3 \\
Mogi-Guaçu River, SP & 46 & $14 \mathrm{M}+20 \mathrm{SM}+10 \mathrm{ST}+6 \mathrm{~A}$ & 4 \\
Mogi-Guaçu River, SP & 46 & $13 \mathrm{M}+20 \mathrm{SM}+8 \mathrm{ST}+5 \mathrm{~A}$ & 3 \\
Mogi-Guaçu River, SP & 46 & $12 \mathrm{M}+20 \mathrm{SM}+10 \mathrm{ST}+4 \mathrm{~A}$ & 2 \\
Mogi-Guaçu River, SP & 46 & $12 \mathrm{M}+20 \mathrm{SM}+8 \mathrm{ST}+6 \mathrm{~A}$ & 3 \\
Mogi-Guaçu River, SP & 45 & $12 \mathrm{M}+20 \mathrm{SM}+10 \mathrm{ST}+3 \mathrm{~A}$ & 2 \\
Mogi-Guaçu River, SP & 45 & $13 \mathrm{M}+19 \mathrm{SM}+10 \mathrm{ST}+3 \mathrm{~A}$ & 5 \\
Piracicaba River, SP & 46 & $12 \mathrm{M}+20 \mathrm{SM}+10 \mathrm{ST}+4 \mathrm{~A}$ & 6 \\
Passa-Cinco River, SP & 46 & $14 \mathrm{M}+18 \mathrm{SM}+10 \mathrm{ST}+4 \mathrm{~A}$ & 3 \\
Jacaré-Guaçú River, SP & 46 & $12 \mathrm{M}+20 \mathrm{SM}+8 \mathrm{ST}+6 \mathrm{~A}$ & 3 \\
Barra-Funda Stream, SP & 46 & $12 \mathrm{M}+20 \mathrm{SM}+8 \mathrm{ST}+6 \mathrm{~A}$ & 3 \\
Paiol Grande Creek, SP & 48 & $12 \mathrm{M}+20 \mathrm{SM}+12 \mathrm{ST}+4 \mathrm{~A}$ & 7 \\
Sapucaí River, MG & 48 & $8 \mathrm{M}+18 \mathrm{SM}+14 \mathrm{ST}+8 \mathrm{~A}$ & 8 \\
Juquiá River, SP & 48 & $10 \mathrm{M}+24 \mathrm{SM}+12 \mathrm{ST}+2 \mathrm{~A}$ & 4 \\
Paraibuna River, SP & 48 & $8 \mathrm{M}+18 \mathrm{SM}+12 \mathrm{ST}+10 \mathrm{~A}$ & 6 \\
Porta Stream, MG & 48 & $8 \mathrm{M}+10 \mathrm{SM}+24 \mathrm{ST}+6 \mathrm{~A}$ & 6 \\
Porta Stream, MG & 48 & $10 \mathrm{M}+14 \mathrm{SM}+14 \mathrm{ST}+10 \mathrm{~A}$ & 3 \\
São Francisco River, MG & 46 & $6 \mathrm{M}+24 \mathrm{SM}+8 \mathrm{ST}+8 \mathrm{~A}$ & 6 \\
São Francisco River, MG & 46 & $8 \mathrm{M}+22 \mathrm{SM}+8 \mathrm{ST}+8 \mathrm{~A}$ & 3 \\
\hline
\end{tabular}

*1 - Present work, 2 - Pazza et al. (2006), 3 - Heras (1998), 4 - Morelli et al. (1983), 5 - Daniel-Silva and Almeida-Toledo (2001), 6 - Justi (1993), 7 - Centofante et al. (2003), 8 - Swerts et al. (1998).

northeastern regions and other basins. Active NORs have frequently been detected on the short arms of SM chromosomes and, occasionally, on the telomeres of ST-A chromosomes in most southeastern populations of $A$. fasciatus (Pazza et al., 2006). On the other hand, the populations analyzed in the present study usually presented NORs at the terminal regions of the long arms of a subtelocentric pair, suggesting that the three populations share a common origin. The reason(s) for the fixation of a differentiated active NOR pattern in A. fasciatus populations from the northeast of Brazil remain(s) unclear, but a putative adaptive role might be inferred.

Multiple NORs have been reported in this species, ranging from one to ten NOR-bearing chromosomes (Pazza, 2005). However, in the present work, most silverstained metaphases revealed single NORs, excepting some individuals from Contas River that presented up to five 
marked chromosomes. Further studies, involving basespecific fluorochrome staining and in situ hybridization with ribosomal probes should be carried out in order to verify whether this condition extends to the other populations or characterizes a population marker.

Apart from evidence of inter-population divergence, the cytogenetic analyses in $A$. fasciatus revealed some similarities in features amongst karyotypes from distinct localities. For instance, the presence of, at least, four metacentric chromosome pairs and a remarkably larger first pair is common to all $2 n=48$ populations studied so far. The presence of unchanged and homeologous chromosome pairs within dynamic karyotypes was previously reported in Astyanax species (Daniel-Silva and Almeida-Toledo, 2001). Such conserved chromosomes can be potentially used for phylogenetic inferences within and between related groups, helping elucidate inter- and intra-specific relationships.

\section{Final Remarks}

Based on morphometric and cytogenetic analyses, the present data present the first information about genetic diversity in the characin $A$. fasciatus from typical northeastern river basins. Both morphological and chromosomal studies were congruent. Similarly, RAPD-PCR, meristic, and morphometric analyses in five samples of Astyanax aff. bimaculatus separated by waterfalls and dams along Doce River basin have shown a concordance between molecular and morphological data (Paiva et al., 2006). Microsatellite, allozymes, mtDNA, and morphometric studies in sympatric populations of the catfish Clarias gariepinus and $C$. anguillaris have all confirmed the presence of distinct species (Agnèse et al., 1997). These data reveal that, in the lack of more expensive and/or advanced technologies, morphological features can be successfully used to support other sources of genetic information.

Besides interpopulation differences, we also describe new cytotypes of $A$. fasciatus, corroborating the extensive karyotype variability in this species. Despite a probable misclassification of chromosomal morphology that might have led to an increased karyotype variation amongst populations studied by distinct authors, it is clear that $A$. fasciatus presents an accentuated plasticity. It is also demonstrated that even within small and closely related hydrographic basins, distinguishable genetic features can be assigned to fish populations. It must be pointed out that Mineiro Stream is located in a typical Atlantic rain forest region, whereas Preto do Costa River is situated in a transition between semi-arid and Atlantic rain forest, and the studied portion of Contas River is in a semi-arid region. Possibly, such environmental differences might characterize distinct selective pressures acting on each population, which would play a major role in phenotypic aspects. As a matter of fact, morphometric data revealed striking differences among populations when compared to cytogenetic results. However, further genetic studies involving refined cytogenetic and/or molecular techniques along these river basins may eventually demonstrate a higher differentiation among populations.

Our results, taken together with previous reports on both cytogenetic and morphological analyses (e.g., Centofante et al., 2003), indicate the existence of well-differentiated populations of $A$. fasciatus along Brazilian hydrographic systems. The level of divergence between them suggests the occurrence of a species complex, widespread throughout distinct river basins. A similar situation has been described in several neotropical fishes, particularly within Astyanax (Moreira-Filho and Bertollo, 1991; Melo and Buckup, 2006), showing that more detailed taxonomical reviews should be carried out in order to provide a reliable scenario about the diversity of the Brazilian ichthyofauna.

\section{Acknowledgments}

The authors would like to thank Conselho Nacional de Desenvolvimento Científico e Tecnológico, Fundação de Amparo à Pesquisa do Estado da Bahia and Universidade Estadual do Sudoeste da Bahia for the financial support.

\section{References}

Agnèse JF, Teugels GG, Galbusera P, Guyomard R and Volckaert F (1997) Morphometric and genetic characterization of sympatric populations of Clarias gariepinus and C. anguillaris from Senegal. J Fish Biol 50:1142-11157.

Almeida-Toledo LF, Foresti F and Toledo-Filho SA (2000) Karyotypic evolution in neotropical freshwater fish. Chrom Today 13:169-182.

Bertaco VA and Lucena CAS (2006) Two new species of Astyanax (Ostariophysi, Characiformes, Characidae) from eastern Brazil, with a synopsis of the Astyanax scabripinnis species complex. Neotrop Ichthyol 4:53-60.

Bertollo LAC, Takahashi CS and Moreira-Filho O (1978) Cytotaxonomic considerations on Hoplias lacerdae (Pisces, Erythrinidae). Braz J Genet 1:103-120.

Cavalcanti MJ and Lopes PRD (1991) Morfometria comparada de Ctenosciaena gracilicirrhus, Paralonchurus brasiensis e Micropogonias furnieri (Teleostei, Scianidae) pela análise multivariada de redes de treliças. Rev Bras Zool 77:627635.

Cavalcanti MJ and Lopes PRD (1993) Análise morfométrica multivariada de cinco espécies de Serranidae (Teleostei, Perciformes). Acta Biol Leopoldensia 15:53-64.

Centofante L, Bertollo LAC, Justi AJ and Moreira-Filho O (2003) Correlation of chromosomal and morphologic characters in two Astyanax species (Teleostei, Characidae). Ichthyol Explor Freshw 14:361-368.

Cruz CD and Carneiro PCS (2003) Modelos Biométricos Aplicados ao Melhoramento Genético. Editora UFV, Viçosa, 585 pp.

Cruz CD and Regazzi AJ (2001) Modelos Biométricos Aplicados ao Melhoramento Genético. Editora UFV, Viçosa, 390 pp. 
Daniel-Silva MFZ and Almeida-Toledo LF (2001) Chromosome R-banding pattern and conservation of a marker chromosome in four species, genus Astyanax (Characidae, Tetragonopterinae). Caryologia 54:209-215.

Heras MP (1998) Estudos citogenéticos em Astyanax fasciatus (Pisces, Characidae) de rios do Brasil. Master's Thesis, Universidade Federal de São Carlos, São Carlos.

Howell WM and Black DA (1980) Controlled silver staining of nucleolus organizer region with protective colloidal developer: A 1-step method. Experientia 36:1014-1015.

Justi AJ (1993) Caracterização cariotípica de populações de Astyanax fasciatus (Cuvier, 1819), Pisces, Characidae, em três bacias hidrográficas. Master's Thesis, Universidade Federal de São Carlos, São Carlos.

Lagler KF, Bardach JE, Miller RR and Passino DRN (1977) Ichthyology. John Wiley \& Sons Ltd, New York, 506 pp.

Levan A, Fredga K and Sandberg AA (1964) Nomenclature for centromeric position on chromosomes. Hereditas 52:201220 .

Melo FAG and Buckup PA (2006) Astyanax henseli, a new name for Tetragonopterus aeneus Hensel, 1870 from southern Brazil (Teleostei, Characiformes). Neotrop Ichthyol 4:4552 .

Molina WF (2001) An alternative method for mitotic stimulation in fish cytogenetics. Chrom Sci 5:149-152.

Moreira-Filho O and Bertollo LAC (1991) Astyanax scabripinnis (Pisces, Characidae): A species complex. Braz J Genet 14:331-357.

Morelli S, Bertollo LAC, Foresti F, Moreira-Filho O and Toledo Filho SA (1983) Cytogenetic considerations on the genus Astyanax (Pisces, Characidae). I. Karyotype variability. Caryologia 36:235-244.
Paiva SR, Dergam JA and Andrade FM (2006) Determining management units in southeastern Brazil: The case of Astyanax bimaculatus (Linnaeus, 1758) (Teleostei, Ostariophysi, Characidae). Hydrobiologia 560:393-404.

Pazza R (2005). Contribuição citogenética à análise da biodiversidade em Astyanax fasciatus (Pisces, Characidae). PhD Thesis, Universidade Federal de São Carlos, São Carlos.

Pazza R, Kavalco KF and Bertollo LAC (2006) Chromosomal polymorphism in Astyanax fasciatus (Teleostei, Characidae) I. Karyotype analysis, Ag-NOR and mapping of the $18 \mathrm{~S}$ and $5 \mathrm{~S}$ ribosomal genes in sympatric karyotypes and their possible hybrid forms. Cytogenet Genome Res 112:313-319.

Reis FS, Pessoa ML and Strauss R (1990) Application of size-free canonical discriminant analysis to studies of geographic differentiation. Braz J Genet 13:509-520.

Reis RE, Kullander SO and Ferrari Jr CJ (2003) Checklist of the Freshwater Fishes of South and Central America. Edicpucrs, Porto Alegre, 742 pp.

Rosa RS, Menezes NA, Britski HA, Costa WJEM and Groth F (2003) Diversidade, padrões de distribuição e conservação dos peixes da Caatinga. In: Leal IL, Tabarelli $\mathrm{M}$ and Silva JMC (eds) Ecologia e Conservação da Caatinga. Ed. Universitária da UFPE, Recife, pp 135-173.

SAS - Statistical Analysis System (1997) User's Guide, Version 6. SAS Institute Inc, Cary, NC.

Sneath PHA and Sokal RR (1973) Numerical Taxonomy. The Principles and Practice of Numerical Classification. WH Freeman and Co., San Francisco, 573 pp.

Swerts CP, Castro GC, Maistro EL, Foresti F and Oliveira C (1998) Análises citogenéticas preliminares na espécie Astyanax fasciatus (Pisces, Characidae) proveniente do rio Sapucaí, represa de Furnas, MG. Genet Mol Biol 21 (suppl. 3):66.

Associate Editor: Luiz Antonio Carlos Bertollo

License information: This is an open-access article distributed under the terms of the Creative Commons Attribution License, which permits unrestricted use, distribution, and reproduction in any medium, provided the original work is properly cited. 